\title{
Evaluasi Penerapan Akuntansi Penerimaan Dana Transfer Pada Badan Pengelola Keuangan dan Barang Milik Daerah Provinsi Sulawesi Utara
}

\author{
Oleh: \\ Indah Helda Wantah' \\ David P.E. Saerang 2 \\ Lidia Mawikere
}

\author{
12 Fakultas Ekonomi Dan Bisnis \\ Universitas Sam Ratulangi Manado \\ Email : 1indah.helda@yahoo.co.id \\ 2lidiamawikere78@gmail.com
}

\begin{abstract}
Each SKPD who has the task of picking and receiving local revenue collection and acceptance shall perform under the terms set out in the legislation. The purpose of this study was to determine the application of accounting receipt of funds transfer in Financial Management Board and Regional Property North Sulawesi Province. Accounting receipt of funds transfer includes a series of activities of receiving, recording, distribution and accountability in the management of money that is the Regional Finance Management Unit (SKPKD) and / or Unit (SKPD). The method used is descriptive qualitative. Based on this study, the obtained results that the Financial Management Board and Regional Property North Sulawesi receive funds transfers from the center, are recorded in the form of journal and distribution in accordance with applicable regulations, and accountability made in the financial statements. However, the Financial Management Board and Regional Property North Sulawesi need to improve the understanding of the technical terms for each employee.
\end{abstract}

Keywords : Evaluation, Application of Accounting, Revenue, Funds Transfer

\section{PENDAHULUAN}

Perubahan sistem pemerintahan dari sistem terpusat menjadi sistem otonomi daerah telah memberi dampak yang besar pada sistem penyelenggaraan pemerintahan dan ruang lingkup kinerja. Hal ini menuntut Pemerintahan Daerah untuk lebih memberikan pelayanan publik yang berdasar pada asas-asas pelayanan publik yang meliputi: transparansi, akuntabilitas, kondisional, partisipatif, kesamaan hak, keseimbangan hak dan kewajiban untuk tercapainya good governance. Perubahan tersebut juga memberi dampak pada pengaturan sistem keuangan pemerintahan di daerah. Untuk mencapai hal tersebut maka diperlukan pengembangan sistem penyelenggaraan pemerintah dengan memanfaatkan kemajuan teknologi informasi dan ilmu pengetahuan sehingga tersedianya data dan informasi pada instansi pemerintah yang dapat dianalisis dan dimanfaatkan secara tepat, akurat dan aman.

Pemerintah daerah dalam menjalankan kegiatan operasionalnya akan terlibat dalam aktivitas penerimaan dan pengeluaran. Berbagai macam pengeluaran ditujukan untuk memperoleh penerimaan, sedangkan penerimaan menjadi sumber dana yang sangat berperan penting dalam menunjang kelancaran roda pemerintahan dan pembangunan daerah sehingga kedua hal tersebut harus diolah secara efektif dan seefesien mungkin.

Penerimaan dana transfer merupakan bagian dalam aktivitas penerimaan daerah yang dimana pelaksanaannya telah diatur oleh negara melalui Menteri Keuangan Republik Indonesia. Dana transfer merupakan dana yang bersumber dari pendapatan APBN yang dialokasikan kepada daerah untuk mendanai kebutuhan Daerah dalam rangka pelaksanaan desentralisasi. Dana Transfer selain 
dimaksudkan untuk membantu Daerah dalam mendanai kewenangannya, juga bertujuan untuk mengurangi ketimpangan sumber pendanaan pemerintahan antara Pusat dan Daerah serta untuk mengurangi kesenjangan pendanaan pemerintahan antar-Daerah. Pendanaan tersebut menganut prinsip money follows function, yang mengandung makna bahwa pendanaan mengikuti fungsi pemerintahan yang menjadi kewajiban dan tanggung jawab masing-masing tingkat pemerintahan. Jenis Dana Transfer meliputi Dana Bagi Hasil (DBH), Dana Alokasi Umum (DAU) dan Dana Alokasi Khusus (DAK).

Badan Pengelola Keuangan dan Barang Milik Daerah merupakan unsur pendukung tugas gubernur yang mempunyai tugas untuk melaksanakan penyusunan dan pelaksanaan kebijakan daerah yang bersifat spesifik di bidang pengelolaan keuangan dan barang milik daerah. Mengingat peranannya sangat penting dalam mengelola keuangan terlebih khusus dalam hal penerimaan dana transfer dari pusat ke daerah sehingga penelitian ini perlu untuk dilakukan.

Hal tersebut menjadi perhatian penulis sehingga tertarik untuk melakukan penelitian lebih lanjut mengenai Penerapan Akuntansi Penerimaan Dana Transfer pada Badan Pengelola Keuangan dan Barang Milik Daerah Provinsi Sulawesi Utara.

Penelitian ini berusaha menjawab pertanyaan, apakah penerapan akuntansi penerimaan dana transfer pada Badan Pengelola Keuangan dan Barang Milik Daerah Provinsi Sulawesi Utara sudah sesuai dengan Peraturan Menteri Dalam Negeri Nomor 59 Tahun2007?

\section{TINJAUAN PUSTAKA}

Suhayati dan Anggadini (2009:2) menyatakan bahwa Akuntansi adalah semua proses yang meliputi identifikasi, pengukuran dan pelaporan informasi ekonomi. Kieso, dkk (2007:2) menyatakan bahwa Akuntansi adalah pengidentifikasian, pengukuran, dan pengkomunikasian informasi keuangan tentang entitas ekonomi kepada pihak yang berkepentingan.

Mursyidi (2009:1) dalam bukunya Akuntansi Pemerintahan di Indonesia menyatakan bahwa Akuntansi Pemerintahan adalah mekanisme teknik dan analisis akuntansi yang diterapkan pada pengelolaan dana masyarakat dilembaga-lembaga tinggi Negara dan departemen-departemen di bawahnya. Nordiawan dan Hertianti (2010:4), menyatakan bahwa Akuntansi Sektor Publik adalah sebuah entitas ekonomi yang menyediakan barang dan/atau jasa publik untuk meningkatkan kesejahteraan masyarakat dan bukan untuk mencari keuntungan finansial.

Akuntansi keuangan daerah adalah proses pengidentifikasian, pengukuran, pencatatan, dan pelaporan transaksi ekonomi (keuangan) dari entitas pemerintah daerah (kabupaten, kota atau provinsi) yang dijadikan sebagai informasi dalam rangka pengambilan keputusan ekonomi oleh pihak-pihak eksternal entitas pemerintah daerah (kabupaten, kota atau provinsi) yang memerlukan. (Halim, 2013: 43)

Hariadi, dkk (2010:118), menyatakan bahwa sistem akuntansi pemerintahan daerah menurut Permendagri Nomor 59 Tahun 2007 pasal 232 ayat (3) meliputi serangkaian prosedur, mulai dari proses pengumpulan data, pencatatan, penggolongan, dan peringkasan atas transaksi dan/atau kejadian keuangan serta pelaporan keuangan dalam rangka pertanggungjawaban pelaksanaan APBD yang dapat dilakukan secara manual atau menggunakan aplikasi komputer. Untuk menyelenggarakan akuntansi pemerintahan daerah, kepala daerah menetapkan sistem akuntansi penerimaan daerah dengan mengacu pada peraturan daerah tentang pokok-pokok pengelolaan keuangan daerah, serta disusun dengan berpedoman pada prinsip pengendalian intern dan standar akuntansi pemerintahan.

Ketentuan Pasal 233 dari Peraturan Menteri Dalam Negeri Nomor 59 Tahun 2007 yang merupakan pedoman pelaksanaan terhadap Peraturan Pemerintah tentang pengelolaan keuangan daerah menyebutkan bahwa sistem akuntansi pemerintahan daerah dilaksanakan oleh pejabat pengelola keuangan daerah (PPKD) pada satuan kerja pengelola keuangan daerah (SKPKD) dan sistem akuntansi Satuan Kerja Perangkat Daerah (SKPD) dilaksanakan oleh Pejabat Penatausahaan Keuangan Satuan Kerja Perangkat Daerah (PPK-SKPD). Sistem akuntansi Pemerintahan daerah secara garis besar terdiri atas: 
1. Sistem Akuntansi pada Satuan Kerja Pengelola Keuangan Daerah (SKPKD), yaitu:
a. Prosedur Akuntansi Penerimaan Daerah
b. Prosedur Akuntansi Pengeluaran Kas
c. Prosedur Akuntansi Aset Tetap
d. Prosedur Akuntansi Selain Kas.

2. Sistem Akuntansi pada Satuan Kerja Perangkat Daerah (SKPD), yaitu:
a. Prosedur Akuntansi Penerimaan Daerah
b. Prosedur Akuntansi Pengeluaran Kas
c. Prosedur Akuntansi Aset Tetap
d. Prosedur Akuntansi Selain Kas.

Keuangan Daerah adalah semua hak dan kewajiban daerah dalam rangka penyelenggaraan pemerintahan daerah yang dapat dinilai dengan uang termasuk di dalamnya segala bentuk kekayaan yang berhubungan dengan hak dan kewajiban daerah tersebut. Untuk itu keuangan daerah harus dikelola dengan benar agar pemerintahan di daerah dapat berjalan dengan baik sehingga dapat menciptakan kesejahteraan bagi masyarakat. Ruang Lingkup Keuangan Daerah sesuai dengan Peraturan Pemerintah Nomor 58 Tahun 2005 adalah sebagai berikut:
a. Hak daerah;
b. Kewajiban daerah;
c. Penerimaan daerah;
d. Pengeluaran daerah;
e. Kekayaan daerah;
f. Kekayaan pihak lain.

Pejabat-pejabat yang terlibat dalam pengelolaan keuangan daerah berdasarkan Permendagri No. 59 Tahun 2007 dimulai dari:

a. Kepala daerah selaku kepala pemerintah daerah

b. Sekretaris Daerah selaku koordinator pengelolaan keuangan Daerah

c. Kepala SKPD selaku PPKD (Pejabat Pengelola Keuangan Daerah)

d. Kepala SKPD selaku Pejabat Pengguna Anggaran/Pengguna Barang

e. Pejabat Kuasa Pengguna Anggaran/Kuasa Pengguna Barang

f. PPTK selaku Pejabat Pelaksana Teknis Kegiatan SKPD

g. Pejabat Penatausahaan Keuangan SKPD (PPK-SKPD)

h. Bendahara Penerimaan dan Bendahara Pengeluaran

Mahsun, dkk (2013:245) menyatakan dana merupakan suatu kesatuan fiskal dan kesatuan akuntansi yang berdiri sendiri dan mempunyai seperangkat rekening yang saling berimbang untuk membukukan kas, sumber keuangan lainnya, kewajiban serta ekuitas, yang dipisahkan sesuai dengan tujuan dalam menjalankan kegiatan tertentu dan berdasarkan peraturan dan ketentuan khusus.

Peraturan Menteri Keuangan Republik Indonesia Nomor 06/ PMK.07/ 2012, Transfer ke Daerah adalah bagian dari belanja negara dalam rangka mendanai pelaksanaan desentralisasi fiskal berupa dana perimbangan, dana otonomi khusus, dan dana penyesuaian.

Ruang Lingkup Pelaksanaan dan Pertanggungjawaban Anggaran Transfer ke Daerah menurut Peraturan Menteri Keuangan Republik Indonesia Nomor 06/PMK.07/ 2012 meliputi:

a. Jenis Anggaran Transfer ke Daerah;

b. Penetapan Alokasi Anggaran Transfer ke Daerah;

c. Pengguna Anggaran/Kuasa Pengguna Anggaran Transfer ke Daerah;

d. Dokumen Pelaksanaan Anggaran Transfer ke Daerah;

e. Tata Cara Pelaksanaan Anggaran Transfer ke Daerah;

f. Rekening Kas Umum Daerah; dan

g. Penatausahaan dan Pertanggungjawaban Anggaran Transfer ke Daerah. 


\section{METODE PENELITIAN}

\subsection{Data}

Prosedur yang dilakukan dalam skripsi ini menggunakan tahap penelitian yang berhubungan dengan masalah yang diteliti. Tahapan-tahapan tersebut yakni sebagai berikut.

1. Mengidentifikasi permasalahan untuk dipecahkan melalui metode deskriptif.

2. Merumuskan permasalahan yang jelas dan menentukan tujuan dan manfaat penelitian.

3. Mengumpulkan informasi yang mengenai gambaran umum instansi dan data mengenai laporan keuangan pada Badan Pengelola Keuangan dan Barang Milik Daerah Provinsi Sulawesi Utara.

4. Melakukan analisis data yang diperoleh dengan menggunakan analisis deskriptif yang bertujuan untuk mengetahui penyajian data laporan keuangan pada Badan Pengelola Keuangan dan Barang Milik Daerah Provinsi Sulawesi Utara telah sesuai dengan peraturan yang berlaku.

5. Mengajukan kesimpulan yang logis berdasarkan hasil penelitian tersebut dan memberikan saransaran pada Badan Pengelola Keuangan dan Barang Milik Daerah Provinsi Sulawesi Utara.

Berdasarkan bentuk dan sifatnya, data penelitian dapat dibedakan dalam dua jenis yaitu data kualitatif (yang berbentuk kata-kata/kalimat) dan data kuantitatif (yang berbentuk angka). Adapun jenis data yang digunakan dalam penelitian ini adalah data kualitatif yang berbentuk kata-kata, bukan dalam bentuk angka. Data kualitatif diperoleh melalui berbagai macam teknik pengumpulan data yaitu wawancara langsung, studi dokumentasi, pengamatan/observasi.

Sumber data yang dipakai dalam penelitian ini adalah data primer yaitu data yang dikumpulkan secara langsung dari obyek yang diteliti (data-data dari hasil wawancara dengan Kepala Bagian Akuntansi Badan Pengelola Keuangan dan Barang Milik Daerah) dan data sekunder yaitu data yang diperoleh tidak dari sumbernya langsung melainkan sudah dikumpulkan oleh pihak lain dan sudah diolah (Visi Misi Pemerintah Provinsi Sulawesi Utara, Struktur Organisasi, Tugas dan Fungsi, Laporan Realisasi Anggaran TA 2011 sampai TA 2013, Pencatatan jurnal).

Penelitian ini dilakukan di Badan Pengelola Keuangan dan Barang Milik Daerah Provinsi Sulawesi Utara yang bertempat di Jalan 17 Agustus No. 69, Manado (Kompleks Kantor Gubernur). Adapun waktu penelitian dimulai dari bulan Februari 2015.

\section{HASIL ANALISIS DAN PEMBAHASAN}

Penerimaan daerah dalam rangka pelaksanaan urusan pemerintahan daerah tertuang dalam Anggaran Pendapatan dan Belanja Daerah (APBD). Setiap SKPD yang mempunyai tugas memungut dan/atau menerima pendapatan daerah wajib melaksanakan pemungutan dan/atau penerimaan berdasarkan ketentuan yang ditetapkan dalam peraturan perundang-undangan.

Kepala Daerah menentukan Kas Umum Daerah sebagai tempat penyimpanan uang daerah. Pemerintah Provinsi membuka rekening pada Bank Sulut sebagai Bank Kas Umum.

Salah satu penerimaan daerah pada Badan Pengelola Keuangan dan Barang Milik Daerah yaitu pendapatan transfer dimana penerimaan tersebut diperoleh dari pemerintah pusat. Pendapatan transfer diberikan untuk semua SKPD yang ada dalam rangka pelaksanaan kegiatan pemerintahan dimasingmasing SKPD. Penerimaan pendapatan transfer disampaikan oleh pemerintah pusat kepada BPKBMD sebagai penerima kemudian menyalurkannya sesuai dengan ketentuan dan besar dana yang telah ditentukan. Dana transfer ke Provinsi Sulawesi Utara, yaitu: Dana Bagi Hasil Pajak (DBH PBB), Dana Bagi Hasil Bukan Pajak (DBH SDA), Dana Alokasi Umum (DAU), Dana Alokasi Khusus (DAK), dan Dana Penyesuaian. 
Tabel 1. Dana Bagi Hasil Pajak (DBH PBB)

\begin{tabular}{|c|c|c|c|}
\hline \multirow{2}{*}{} & \multirow{2}{*}{$\begin{array}{c}\text { Anggaran } \\
(\mathbf{R p})\end{array}$} & \multicolumn{2}{|c|}{ Realisasi } \\
\cline { 3 - 4 } & & $\mathbf{( R p )}$ & $\mathbf{( \% )}$ \\
\hline 2011 & 72.659 .331 .620 .00 & 75.806 .471 .171 .00 & 104,33 \\
\hline 2012 & 77.650 .000 .000 .00 & 92.316 .875 .921 .00 & 118,89 \\
\hline 2013 & 97.300 .000 .000 .00 & 84.163 .969 .926 .00 & 86,50 \\
\hline
\end{tabular}

Sumber: BPKBMD Prov. Sulawesi Utara

Tabel 1 menunjukkan bahwa pada tahun 2011 dan tahun 2012, penerimaan DBH PBB melebihi target yang dianggarkan. Tetapi pada tahun 2013 mengalami penurunan yang cukup berarti. Tahun 2011, realisasi penerimaan DBH PBB sebesar 75.806.471.171.00 kemudian meningkat pada tahun 2012 menjadi 92.316.875.921.00, dan selanjutnya menurun pada tahun 2013 ke angka 84.163.969.926.00.

Tabel 2. Dana Bagi Hasil Bukan Pajak (DBH SDA)

\begin{tabular}{|c|c|c|c|}
\hline \multirow{2}{*}{} & \multirow{2}{*}{$\begin{array}{c}\text { Anggaran } \\
(\mathbf{R p})\end{array}$} & \multicolumn{2}{|c|}{ Realisasi } \\
\cline { 2 - 4 } & $\mathbf{( R p )}$ & $\mathbf{( \% )}$ \\
\hline 2011 & 700.912 .235 .00 & 4.555 .464 .002 .00 & 649,93 \\
\hline 2012 & 1.350 .000 .000 .00 & 6.975 .400 .509 .00 & 516,70 \\
\hline 2013 & 6.700 .000 .000 .00 & 5.651 .106 .978 .00 & 84,34 \\
\hline
\end{tabular}

Sumber: BPKBMD Prov. Sulawesi Utara

Tabel 2 memperlihatkan bahwa presentase realisasi anggaran dari tahun 2011 sampai tahun 2013 mengalami penurunan yang cukup signifikan, dari angka 649,93\% pada tahun 2011, turun menjadi 516,70\% pada tahun 2012, dan lebih turun lagi ke angka 84,34\% pada tahun 2013.

Tabel 3. Dana Alokasi Umum (DAU)

\begin{tabular}{|c|c|c|c|}
\hline & \multirow{2}{*}{$\begin{array}{c}\text { Anggaran } \\
(\mathbf{R p})\end{array}$} & \multicolumn{2}{|c|}{ Realisasi } \\
\cline { 3 - 4 } & & $\mathbf{( R p )}$ & $\mathbf{( \% )}$ \\
\hline 2011 & 619.711 .007 .00 .00 & 619.711 .007 .00 .00 & 100,00 \\
\hline 2012 & 790.534 .491 .000 .00 & 790.534 .491 .000 .00 & 100,00 \\
\hline 2013 & 885.684 .277 .000 .00 & 885.684 .277 .000 .00 & 100,00 \\
\hline
\end{tabular}

Sumber:BPKBMD Prov. Sulawesi Utara

Tabel 3 menunjukkan penerimaan DAU dari tahun 2011 sampai tahun 2013 terus mengalami kenaikan dan penerimaan tersebut terealisasi sesuai dengan target yang ada. Tahun 2011 menerima 619.711.007.00.00, kemudian pada tahun 2012 sebesar 790.534.491.000.00, dan pada tahun 2013 meningkat lagi menjadi 885.684.277.000.00. 
Tabel 4. Dana Alokasi Khusus (DAK)

\begin{tabular}{|c|c|c|c|}
\hline \multirow{2}{*}{} & \multirow{2}{*}{$\begin{array}{c}\text { Anggaran } \\
(\mathbf{R p})\end{array}$} & \multicolumn{2}{|c|}{ Realisasi } \\
\cline { 3 - 4 } & $(\mathbf{R p )}$ & $\mathbf{( \% )}$ \\
\hline 2011 & 29.288 .200 .000 .00 & 29.288 .200 .000 .00 & 100,00 \\
\hline 2012 & 43.539 .930 .000 .00 & 43.539 .930 .000 .00 & 100,00 \\
\hline 2013 & 54.346 .140 .000 .00 & 54.346 .140 .000 .00 & 100,00 \\
\hline
\end{tabular}

Sumber:BPKBMD Prov. Sulawesi Utara

Tabel 4 menunjukkan penerimaan DAK dari tahun 2011 sampai tahun 2013 yang terus mengalami kenaikan dan penerimaan tersebut terealisasi sempurna dengan mencapai presentase $100 \%$. Pada tahun 2011 dianggarkan dan terealisasi sebesar 29.288.200.000.00, kemudian tahun 2012 sebesar 43.539.930.000.00, selanjutnya tahun 2013 sebesar 54.346.140.000.00.

Tabel 5. Dana Penyesuaian

\begin{tabular}{|c|c|c|c|}
\hline \multirow{2}{*}{} & \multirow{2}{*}{$\begin{array}{c}\text { Anggaran } \\
(\mathbf{R p})\end{array}$} & \multicolumn{2}{|c|}{ Realisasi } \\
\cline { 3 - 4 } & & $\mathbf{R p )}$ & $\mathbf{( \% )}$ \\
\hline 2011 & 100.684 .749 .000 .00 & 100.684 .749 .000 .00 & 100,00 \\
\hline 2012 & 278.491 .044 .000 .00 & 267.389 .841 .500 .00 & 96,01 \\
\hline 2013 & 255.154 .860 .000 .00 & 241.963 .973 .500 .00 & 94,83 \\
\hline
\end{tabular}

Sumber:BPKBMD Prov. Sulawesi Utara

Tabel 5 menunjukkan bahwa penerimaan dana transfer mengalami penurunan demikian pula dengan realisasi anggarannya. Pada tahun 2011 terealisasi sempurna pada angka 100\%, kemudian pada tahun 2012 yang terealisasi hanya 96,01\%, dan selanjutnya pada tahun 2012 hanya 94,83\% yang terealisasi dari yang dianggarkan.

Tabel 6. Jurnal Penerimaan Dana Transfer

\begin{tabular}{|c|c|c|c|}
\hline Tgl/Bln/Thn & Keterangan & Debit & Kredit \\
\hline $\mathrm{Xxx}$ & Kas di Kas Daerah & $\mathrm{Xxx}$ & \\
\cline { 2 - 4 } & $\begin{array}{c}\text { R/K SKPD } \\
\text { (Dana Transfer) }\end{array}$ & & $\mathrm{Xxx}$ \\
\hline
\end{tabular}

Sumber:BPKBMD Prov. Sulawesi Utara

Tabel 6 menunjukkan cara pencatatan jurnal penerimaan dana transfer yaitu kas daerah pada posisi debit dan dana transfer pada posisi kredit.

Penerimaan dana transfer pada Badan Pengelola Keuangan dan Barang Milik Daerah Provinsi Sulawesi Utara telah sesuai dengan Peraturan Menteri Dalam Negeri (Permendagri) Nomor 59 Tahun 2007, dimana BPKBMD Sulut menggunakan Peraturan Menteri Keuangan Republik Indonesia Nomor 183/PMK.07/2013 tentang Pelaksanaan dan Pertanggungjawaban Dana Transfer, sebagai petunjuk teknis. Dan sebagai bentuk pertanggungjawaban BPKBMD telah membuat laporan keuangan atas semua penggunaan dana transfer yang sesuai dengan peraturan yang berlaku. 


\section{KESIMPULAN}

Berdasarkan hasil penelitian dan pembahasan yang telah dilakukan dalam menganalisis penerapan akuntansi penerimaan dana transfer pada Badan Pengelola Keuangan dan Barang Milik Daerah Provinsi Sulawesi Utara maka dapat ditarik kesimpulan sebagai berikut ini:

1. Badan Pengelola Keuangan dan Barang Milik Daerah Provinsi Sulawesi Utara menerima dana transfer dari pemerintah pusat yaitu Dana Bagi Hasil (DBH), Dana Alokasi Umum (DAU), Dana Alokasi Khusus (DAK), dan Dana Penyesuaian pada Bank Kas Umum Daerah yang sudah ditentukan yaitu Bank Sulut dan pelaksanaan penerimaan dana transfer dari pusat ke daerah telah sesuai dengan Peraturan Menteri Keuangan Republik Indonesia Nomor 183/PMK.07/2013 dan secara keseluruhan telah sesuai dengan Peraturan Menteri Dalam Negeri (PERMENDAGRI) Nomor 59 Tahun 2007.

2. Setiap penggunaan dana transfer memiliki aturan masing-masing dan Badan Pengelola Keuangan dan Barang Milik Daerah (BPKBMD) telah melakukan aturan-aturan tersebut dalam setiap penggunaan dana sehingga dapat terpakai dengan baik sesuai dengan prosedur yang berlaku.

Saran yang dapat diberikan dari hasil penelitian ini yang dapat dijadikan bahan masukan dan perbaikan bagi Badan Pengelola Keuangan dan Barang Milik Daerah (BPKBMD) Provinsi Sulawesi Utara yakni, Sistem penerimaan dana transfer dari pusat pada Badan Pengelola Keuangan dan Barang Milik Daerah Provinsi Sulawesi Utara sudah baik secara administratif dan transparan pada publik namun perlu meningkatkan pemahaman dari segi teknis untuk setiap staf/ pegawai. Sistem penerimaan dana transfer serta laporan keuangan Badan Pengelola Keuangan dan Barang Milik Daerah Provinsi Sulawesi Utara sudah baik dan transparan sehingga sudah bisa menjadi contoh oleh satuan kerja lain di pemerintah Provinsi Sulawesi Utara hingga ke pemerintah kabupaten/kota dalam hal transparansi keuangan pada satuan kerja masing - masing. Diharapkan juga untuk bisa mempertahankan kinerja pertanggung jawaban keuangan yang baik sehingga bisa memberi manfaat dalam proses penyusunan laporan keuangan daerah.

\section{DAFTAR PUSTAKA}

Bastian, Indra. (2006). Akuntansi Sektor Publik: Suatu Pengantar. Erlangga. Jakarta.

Darise, Nurlan. (2008). Akuntansi Keuangan Daerah (Akuntansi Sektor Publik). PT. Indeks. Jakarta.

Darise, Nurlan. (2009). Pengelolaan Keuangan Daerah. Edisi Kedua. PT. Indeks. Jakarta.

Halim, Abdul. (2013). Akuntansi Keuangan Daerah. Edisi Keempat. Salemba Empat. Jakarta.

Hariadi, Pramono. (2010). Pengelolaan Keuangan Daerah. Salemba Empat. Jakarta

Kieso, Donald. (2008). Akuntansi Intermediate. Edisi Keduabelas. Erlangga. Jakarta

Kuncoro, Mudrajad. (2009). Metode Riset untuk Bisnis dan Ekonomi: Bagaimana Meneliti dan Menulis Tesis? Edisi Ketiga. Erlangga. Jakarta.

Mahsun, Mohhamad. (2013). Akuntansi Sektor Publik. BPFE. Yogyakarta

Mardiasmo. (2009). Akuntansi Sektor Publik. ANDI. Yogyakarta.

Mursyidi. (2009). Akuntansi Pemerintahan di Indonesia. Refika Aditama. Bandung

Nordiawan, Deddi. (2010). Akuntansi Sektor Publik. Edisi Kedua. Salemba Empat. Jakarta

Peraturan Menteri Dalam Negeri Nomor 59 Tahun 2007 Tentang Pedoman Pengelolaan Keuangan

Daerah.

Peraturan Menteri Keuangan Republik Indonesia Nomor 06/PMK.07/2012. Tentang Pelaksanaan dan Pertanggungjawaban Anggaran Transfer ke Daerah.

Peraturan Pemerintah Nomor 58 Tahun 2005. Tentang Pengelolaan Keuangan Daerah.

Peraturan Pemerintah Nomor 71 Tahun 2010. Tentang Standar Akuntansi Pemerintahan.

Tamalumu, Jendra. (2014). Penerapan Akuntansi Penerimaan Dana Transfer pada Dinas Pendapatan, Pengelolaan Keuangan dan Aset Kabupaten Kepulauan Sangihe. Skripsi. Universitas Sam Ratulangi. Manado. 
Tamalumu, Satriawan. (2012). Analisis Penerapan Sistem dan Prosedur Penerimaan Kas Berdasarkan Surat Edaran Menteri Dalam Negeri Nomor 900/316/BAKD/2007 Pada Dinas Pendapatan, Pengelolaan Keuangan dan Aset (DPPKA) Kabupaten Kepulauan Sangihe. Skripsi. Universitas Sam Ratulangi. Manado.

Sugiyono. (2011). Metode Penelitian Kuantitatif dan Kualitatif. Alfabeta. Bandung 